\title{
KONDISI OSEANOGRAFI DI SELAT MATAK KABUPATEN KEPULAUAN ANAMBAS MELALUI MODEL HIDRODINAMIKA
}

Oceanographic Conditions in Matak Strait Anambas Island District through Hydrodynamic Model

\author{
Oleh : \\ Agung Riyadi*, Nusa Idaman Said* dan Matih Santos** \\ *Pusat Teknologi Lingkungan - Badan Pengkajian dan Penerapan Teknologi \\ ** Teknologi IImu Kelautan - Institut Pertanian Bogor
}

\begin{abstract}
Abstrak
Tulisan ini berisi tentang kondisi umum beberapa paramater oseanografi perairan Selat Matak Kabupaten Kepulauan Anambas.Data arus diperoleh dengan melakukan pengukuran langsung di lapangan dengan menggunakan alat current meter jenis RCM-7.Simulasi model menggunakan Mike 21. Simulasi pemodelan pola arus terbagi menjadi 2 musim, yaitu musim barat (Bulan Januari) dan musim timur (Bulan Agustus) Pola arus menjelang pasang saat musim barat secara umum bergerak menuju ke arah selatan, hal ini menunjukkan peran pasang surut cukup kuat mempengaruhi pergerakan air di lokasi studi. Kecepatan arus di dalam selat saat menjelang pasang pada musim barat mencapai $1 \mathrm{~m} / \mathrm{s}$. Pola arus saat pasang pada musim barat terlihat masih bergerak menuju ke selatan. Kecepatan arus maksimum di dalam selat saat pasang mencapai $0.32 \mathrm{~m} / \mathrm{s}$, sedangkan kecepatan rata-ratanya di area model adalah $0.12 \mathrm{~m} / \mathrm{s}$. Pola arus menjelang surut masih bergerak menuju ke selatan, hal ini semakin memperkuat dugaan bahwa selain pasang surut peran angin juga sangat signifikan dalam mengerakkan arus, dalam hal ini arus bergerak menuju ke selatan. Kecepatan arus saat menjelang surut mencapai $0.85 \mathrm{~m} / \mathrm{s}$ Pola arus saat surut menunjukkan adanya perbedaan dengan 3 kondisi sebelumnya, yakni arus di dalam selat bergerak keluar ke utara menuju Laut Cina Selatan. Dalam kondisi surut terlihat peran pasut lebih dominan bila dibandingkan angin, hal ini terbukti walaupun angin menuju ke selatan, arus di dalam selat bergerak menuju ke utara mengikuti aliran pasut yang menuju ke laut cina selatan. Kecepatan arus cukup bervariasi dilokasi pemodelan, kecepatan arus saat surut di dalam mencapai $0.5 \mathrm{~m} / \mathrm{s}$, dengan rata-ratanya $0.15 \mathrm{~m} / \mathrm{s}$.
\end{abstract}

Kata kunci:kecepatan arus, arah arus, pasang surut, model.

\begin{abstract}
This paper describes some of the general condition of the oceanographic parameters in the Strait Matak, Anambas Archipelago. The data flow is obtained by direct measurement by using a current meter types RCM-7. Simulation models using Mike 21. Mike flow pattern is divided into two seasons, namely west season (January) and the east season (August) and flow patterns ahead of the tide when the season is generally moving west to wards the south, it demonstrates the role of strong tidal influence the movement of waterin the study area. Flow velocity in the strait just before the tide on the west season reaches $1 \mathrm{~m} / \mathrm{s}$. Flow patterns at high tide on the west season looks still moving toward sthe south. The maximum flow velocity in the strait when the tide reaches $0.32 \mathrm{~m} / \mathrm{s}$, while the average speed in the area of the model is $0.12 \mathrm{~m} / \mathrm{s}$. Low tide towards the current pattern is still moving towards the south, it reinforces the notion that in addition to tidal windsare also very significant role in moving the flow, in this case that the current is moving toward the south. Flow velocity just before low tide reaches $0.85 \mathrm{~m} / \mathrm{s}$. Flow patterns at low tide shows the differences in the three previous conditions, the current in the strait to move out to the north toward the South China Sea. In condition slow tide, the tida Imore dominantly than the wind, this proved to even though the wind toward the south, the currents inthestraitis moving toward snorth along the tidal flow leading to the South China Sea. Flow velocity is quite varied location of modeling; flow velocity at low tide reaches $0.5 \mathrm{~m} / \mathrm{s}$, with the average $0.15 \mathrm{~m} / \mathrm{s}$.
\end{abstract}

Keywords: current and direction, wind, tide, model. 


\section{PENDAHULUAN}

\section{$1.1 \quad$ Latar Belakang}

Kabupaten Kepulauan Anambas adalah kabupaten kepulauan dengan luas wilayah \pm 46.664,15 kilometer persegi, yang terdiri dari perairan laut $\pm 46.056,43$ kilometer persegi $(98,7 \%)$ dan daratan $\pm 607,72$ kilometer persegi $(1,3 \%)$. Luas daratan yang hanya $\pm 607,72$ kilometer persegi (1,3\%) berupa 255 (dua ratus lima puluh lima) pulau besar dan kecil, yang 5 (lima) pulau diantaranya yakni Pulau Tokong Berlayar, Pulau Tokong Nanas, dan Pulau Damar, Pulau Mangkai dan Pulau Tokong Malang Biru berbatasan langsung dengan negara tetangga yakni Vietnam dan Malaysia, dan hingga saat ini pulau-pulau tersebut masih belum berpenghuni.

Lokasi studi terletak di perairan Selat Matak yang terhubung langsung dengan Laut Cina Selatan.Perairan selat umumnya mempunyai karateristik kedalaman perairan yang unik, dimana selalu ada kanal yang relatif dalam di bagian tengah selat.

\subsection{Tujuan dan Sasaran Kajian}

1) Melakukan kajian permodelan arah dan kecepatan arus di Selat Matak Kabupaten Kepulauan Anambas menggunakan metode pemodelan numerik.

2) Melihat tingkat kecepatan arus pada saat musim barat dan musim timur.

Sasaran dari studi ini adalah diketahuinya karateristik dari beberapa komponen oseanografi sebagai dasar untuk pengambilan kebijakan.

\subsection{Ruang Lingkup}

1) Memasang peralatan current meter atau alat mengukur kecepatan dan arah arus di Selat Matak

2) Mengukur kedalaman, dan suhu perairan

3) Membangun model kecepatan dan arah arus dengan software MIKE 21.

\subsection{Lokasi dan waktu kajian}

Lokasi kajian berada dalam suatu Selat yang menghubungkan antara Pulau Bungur dengan Pulau Palmatak di Kabupaten Kepulauan Anambas. Pengambilan sampel lapangan dilaksanakan bulan Oktober 2013.

\section{METODE PENELITIAN}

\subsection{Metode Pengumpulan Data}

Data yang diperlukan untuk informasi komponen hidrooseanografi antara lain: batimetri, pasang surut, gelombang, arus laut, suhu, dan salinitas. Data kelautan dari Dinas Hidro-oceanografi TNI AL. Tabel 1 di bawah ini memperlihatkan metode pengumpulan data untuk komponen hidrooseaografi.

Tabel 1. Metode Pengumpulan Data.

\begin{tabular}{|l|l|l|}
\hline Parameter & $\begin{array}{l}\text { Metode } \\
\text { Pengumpulan Data }\end{array}$ & \multicolumn{1}{|c|}{$\begin{array}{l}\text { Metode } \\
\text { Analisis }\end{array}$} \\
\hline Batimetri & $\begin{array}{l}\text { Data sekunder dari } \\
\text { pengukuran dengan } \\
\text { Fish Finder/Echo- } \\
\text { sounder }\end{array}$ & $\begin{array}{l}\text { Analisis } \\
\text { dengan } \\
\text { peta } \\
\text { berskala }\end{array}$ \\
\hline $\begin{array}{l}\text { Pasang } \\
\text { surut }\end{array}$ & $\begin{array}{l}\text { Data sekunder dari } \\
\text { (Dishidros) }\end{array}$ & $\begin{array}{l}\text { Tipe pasang } \\
\text { surut rumus } \\
\text { Formzahl }\end{array}$ \\
\hline Arus & $\begin{array}{l}\text { Data sekunder } \\
\text { (Dishidros) dan data } \\
\text { primer menggunakan } \\
\text { current meter jenis } \\
\text { RCM-7 untuk validasi } \\
\text { model }\end{array}$ & $\begin{array}{l}\text { Analisis } \\
\text { kecepatan } \\
\text { arus rata- } \\
\text { rata (besar } \\
\text { dan arah) }\end{array}$ \\
\hline Suhu & $\begin{array}{l}\text { Pengukuran langsung } \\
\text { dengan CTD }\end{array}$ & $\begin{array}{l}\text { Fluktuasi } \\
\text { suhu }\end{array}$ \\
\hline
\end{tabular}

Pengukuran secara langsung meliputi kedalaman perairan dandata arus diperoleh dengan melakukan pengukuran langsung dengan menggunakan alat current meter jenis RCM-7. Pengukuran dilakukan dengan cara mooring atau menambat dalam satu titik tetap selama $3 \times 24$ jam. Komponen arus yang terukur berupa arah dan kecepatan berdasarkan waktu. Data arus hasil pengukuran selanjutnya di visualisasi dalam bentuk diagram scatter plot.Data tersebut berfungsi sebagai data untuk validasi model.

Selain melakukan pengukuran juga dilakukan pemodelan numerik untuk mengetahui pola arus secara spasial dan temporal. Model ini menggunakan pendekatan metode beda hingga (finite difference) untuk menyelesaikan persamaan yang digunakan.

\subsection{Metode Pembuatan Model Hidrodinamika}

Data arus diperoleh dengan melakukan pengukuran langsung di lapangan dengan menggunakan alat current meter jenis RCM-7. Komponen arus yang terukur berupa arah dan kecepatan berdasarkan waktu. Data arus hasil pengukuran selanjutnya di visualisasi dalam bentuk diagram scatter plot.

Selain melakukan pengukuran juga dilakukan pemodelan numerik untuk mengetahui pola arus secara spasial dan temporal dengan menggunakan 
model DHI MIKE 21. Model ini menggunakan pendekatan metode beda hingga (finite difference) untuk menyelesaikan persamaan yang digunakan. Adapun persamaan yang digunakan adalah sebagai berikut:

Arah dan kecepatan arus laut merupakan proses komplek karena merupakan dampak dari interaksi pola pasang surut, angin dan kedalaman perairan.Persamaan yang digunakan pada model ini adalah persamaan kontinuitas dan persamaan momentum dengan perata-rataan kedalaman. Model ini menggunakan pendekatan metode beda hingga (finite difference) untuk menyelesaikan persamaan yang digunakan. Adapun persamaan yangdigunakan adalah sebagai berikut:

\section{Persamaan kontinuitas:}

$$
\frac{\partial \zeta}{\partial t}+\frac{\partial p}{\partial x}+\frac{\partial q}{\partial x}=\frac{\partial d}{\partial t}
$$

\section{Persamaan momentum :}

pada sumbu $x$

$$
\begin{aligned}
& \frac{\partial p}{\partial t}+\frac{\partial}{\partial x}\left(\frac{p^{2}}{h}\right)+\frac{\partial}{\partial y}\left(\frac{p q}{h}\right)+g h \frac{\partial \zeta}{\partial x}+\frac{g p \sqrt{p^{2}+q^{2}}}{C^{2} \cdot h^{2}} \\
& -\frac{1}{\rho_{w}}\left[\frac{\partial}{\partial x}\left(h \tau_{x x}\right)+\frac{\partial}{\partial y}\left(h \tau_{x y}\right)\right] \\
& -\Omega_{\mathrm{q}}-f V V_{x}+\frac{h}{\rho_{w}} \frac{\partial}{\partial x}\left(\rho_{a}\right)=0 \\
& \text { pada sumbu y } \\
& \begin{aligned}
\frac{\partial q}{\partial t}+\frac{\partial}{\partial y}\left(\frac{q^{2}}{h}\right)+\frac{\partial}{\partial x}\left(\frac{p q}{h}\right) & +g h \frac{\partial \zeta}{\partial y}+\frac{g p \sqrt{p^{2}+q^{2}}}{C^{2} \cdot h^{2}} \\
-\frac{1}{\rho_{w}}\left[\frac{\partial}{\partial y}\left(h \tau_{y y}\right)\right. & \left.+\frac{\partial}{\partial x}\left(h \tau_{x y}\right)\right]+\Omega_{\mathrm{p}}-f V V_{y} \\
+ & \frac{h}{\rho_{w}} \frac{\partial}{\partial y}\left(\rho_{a}\right)=0
\end{aligned}
\end{aligned}
$$

Dimana:

$h(x, y, t):$ water depth $(=\zeta-d)$

$d(x, y, t)$ :kedalaman yang bervariasi terhadap waktu $\zeta(x, y, t)$ : surface elevation

$p, q(x, y, t)$ : flux densitas pada sumbu $\mathrm{x}$ dan $\mathrm{y}$ $\left(\mathrm{m}^{3} / \mathrm{s} / \mathrm{m}\right)=(u h, v h)$

$u, v$ :kecepatan yang dirata-ratakan terhadap

kedalaman pada sumbux dan y

$C(x, y)$ : Chezy resistance $\left(\mathrm{m}^{1 / 2} / \mathrm{s}\right)$

$g$ : gravitasi $\left(\mathrm{m}^{2} / \mathrm{s}\right)$

$f(\mathrm{~V})$ : faktor gesekan angin

$\mathrm{V}, \mathrm{Vx}, \mathrm{Vy}(\mathrm{x}, \mathrm{y}, \mathrm{t})$ : kecepatan angin pada sumbu $\mathrm{x}$ dan $\mathrm{y}(\mathrm{m} / \mathrm{s})$

$\Omega(\mathrm{x}, \mathrm{y})$ : parameter coriolis

$\rho_{\mathrm{a}}(\mathrm{x}, \mathrm{y})$ :tekanan atmosfer $(\mathrm{kg} / \mathrm{m} / \mathrm{s} 2)$

$\rho_{\mathrm{w}}$ :densitas air laut $(\mathrm{kg} / \mathrm{m} 3)$

$\tau_{\mathrm{xx}}, \tau_{\mathrm{xy}}, \tau_{\mathrm{yy}}$ :komponen shear stress efektifBed shear stress pada arah $\mathrm{x}$ dan $\mathrm{y}$ dapat dihitung dengan(MIKE. 2005.). $\tau_{b x}=\rho c_{f} U \sqrt{U^{2}+V^{2}}\left[1+\left(\frac{\partial z_{b}}{\partial x}\right)^{2}+\left(\frac{\partial z_{b}}{\partial y}\right)^{2}\right]^{\frac{1}{2}}$
$\tau_{b y}=\rho c_{f} V \sqrt{U^{2}+V^{2}}\left[1+\left(\frac{\partial z_{b}}{\partial x}\right)^{2}+\left(\frac{\partial z_{b}}{\partial y}\right)^{2}\right]^{\frac{1}{2}}$

dimana $\mathrm{c}_{\mathrm{f}}$ adalah koefisien gesekan dan dapat dihitung sebagai berikut :

$c_{f}=\frac{g}{C^{2}}=\frac{g n^{2}}{\lambda^{2} H^{1 / 3}}$

dimana

C: Chezy Koefisien

$n$ : Manning Koefisien

$\lambda:$ 1,486 untuk unit Inggris dan 1,0 untuk SI

Kedalaman rata-rata gesekan turbulen dapat dihitung menggunakan konsep viskositas Eddy dari

Boussinesq, yaitu :

$$
\begin{aligned}
& \tau_{x x}=\rho v_{x x}\left(\frac{\partial U}{\partial x}+\frac{\partial U}{\partial x}\right) \\
& \tau_{x y}=\tau_{y x}=\rho v_{x y}\left(\frac{\partial U}{\partial y}+\frac{\partial V}{\partial x}\right) \\
& \tau_{y y}=\rho v_{y y}\left(\frac{\partial V}{\partial y}+\frac{\partial V}{\partial y}\right)
\end{aligned}
$$

dimana, $v$ adalah $0,3 \pm 0,6 U^{*} H$

$\mathrm{V}:$ Kecepatan arus pada arah y

$\mathrm{U} \quad$ : Kecepatan arus pada arah $\mathrm{x}$

Hydrodynamics Module of MIKE 21 Flow Model, 2007

Pengaruh angin di permukaan dinyatakan dalam rumus empirik (Chapra, 1997):

$f\left(U_{w}\right)=19+0.95 U_{w}{ }^{2}$ di mana $U_{w}$ adalah kecepatan angin di permukaan.

\subsection{Input dan Pembangkit Pemodelan Arus}

Beberapa data yang digunakan dalam pemodelan arus adalah batimetri, pasang surut, dan angin. Batimetri digunakan sebagai input dasar pemodelan, sedangkan pasang surut dan angin digunakan sebagai pembangkit model arus.

\subsubsection{Batimetri}

Batimetri yang digunakan yang digunakan dalam pemodelan ini adalah batimetri keluaran DISHIDROS TNI-AL 2012 yang telah di olah sebelumnya. Batimetri juga digunakan untuk penentuan domain model. Dalam studi ini domain model dibuat luas sejauh mungkin dari interest area 
dengan tujuan untuk memperoleh aliran pasut secara benar

\subsubsection{Pasang Surut}

Data pasang surut yang digunakan adalah data ramalan dari AG95 (updated to Andesen 2006) yang dikembangkan oleh Ole Baltazar Andersen. Model ini merupakan suatu model peramalan pasang surut global dengan resolusi $0.25^{\circ} \times 0.25^{\circ}$ yang merupakan data asimilasi dari data TOPEX/Poseidon dengan menggunakan pendekatan finite element.Pada studi ini lokasi pemodelan terdiri dari 4 batas terbuka pasut utama, yakni pasut batas terbuka dari utara dan timur, selatan, dan barat.

Data pasang surut diperoleh dari DISHIDROS TNI-AL stasiun Taremba yang merupakan lokasi terdekat dengan wilayah kajian. Koordinat stasiun tersebut adalah $106^{\circ} 6^{\prime} 60.00^{\prime \prime}$ BT dan $3^{\circ} 8^{\prime} 60.00^{\prime \prime}$ LU. Data yang diperoleh merupakan data komponen pasang surut, selanjutya dari data tersebut dilakukan peramalan pasut dengan menggunakan perangkat lunak Worldtide untuk memperoleh elevasi pasang surut. Data komponen pasut juga digunakan untuk mentukan tipe pasang surut dengan formulasi Formzahl berikut

$$
F=\frac{O_{1}+K_{1}}{M_{2}+S_{2}}
$$

dimana:

\section{$\mathrm{F}$ : bilangan Formzahl}

O1 : amplitudo komponen pasut tunggal utama yang disebabkan gaya tarik bulan

K1 : amplitudo komponen pasut tunggal utama yang disebabkan gaya tarik bulan dan matahari

M2 :amplitudo komponen pasut ganda utama yang disebabkan oleh gaya tarik bulan

S2 :amplitudo komponen pasut ganda utama yang disebabkan oleh gaya tarik matahari

Berdasarkan nilai $\mathrm{F}$ tersebut, tipe pasang surut dapat dikelompokkan sebagai berikut:
$\mathrm{F}<0,25$
: pasang surut tipe ganda
$0,26<F<1,50$
: pasang surut campuran condong bertipe ganda
$1,51<\mathrm{F}<3,00 \quad$ : pasang surut campuran condong bertipe tunggal
$\mathrm{F}>3,00$
: pasang surut tunggal

Tunggang pasut (Tidal Range) merupakan selisih antara kondisi muka air tertinggi dan muka air terendah pada saat purnama, dengan persamaan :

Tungang Pasut $=\mathrm{HW}-\mathrm{LW}$

HW : Highest Water (muka air tertinggi)

LW : Lowest Water (muka air terendah)

\subsubsection{Angin}

Data angin masukan model diperoleh dari ECMWF (European Centre for Medium-Range Weather Forecasts) melalui situs http://www.ecmwf.int.Data ini merupakan data reanalisis dan interpolasi data meteorologi yang diperoleh dari berbagai pusat data pengamatan badan meteorologi dunia.Dalam studi ini data yang digunakan adalah data harian dengan interval waktu per 6 jam pada ketinggian $10 \mathrm{~m}$ di atas permukaan laut dengan resolusi spasial $1.5^{\circ}$ x $1.5^{\circ}$.Gambaran data angin masukan model untuk musim barat (bulan januari) dan musim timur (bulan agustus) di sajikan dalam Gambar 1.

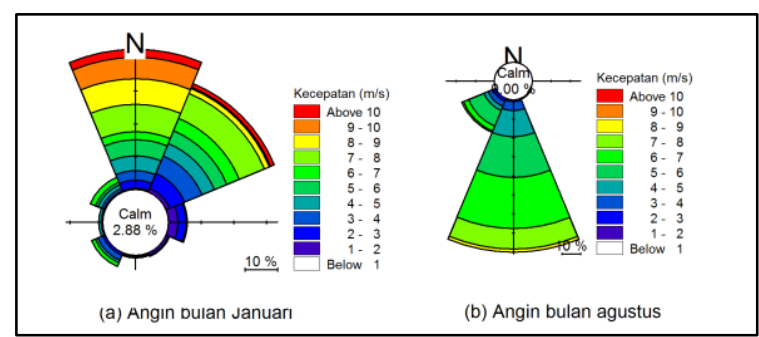

Gambar 1. Wind Rose Daerah Palmatak.

\subsection{Skenario Simulasi Model}

Hidrodinamika akan disimulasikan pada bulan Januari (mewakili musim barat) dan bulan Agustus (mewakili musim timur) dengan tujuan untuk memperoleh pengaruh musiman, selain itu karena lokasi studi terletak di perairan selat pengaruh pasang surut harus di perhitungkan sehingga simulasi akan dilakukan selama 15 hari dengan asumsi akan diperoleh arus yang dipengaruhi kondisi pasang tertinggi dan surut terendah yang signifikan

\section{HASIL DAN PEMBAHASAN}

\subsection{Batimetri}

Hasil pengolahan data batimetri yang diperoleh dari DISHIDROS TNI-AL tersaji pada Gambar 2. Berdasarkan gambar tersebut terlihat kedalaman perairan diwilayah kajian cukup bervariasi hingga $38 \mathrm{~m}$ di bagian tengah selat. Secara membujur utara-selatan variasi kedalaman di tengah selat terlihat cukup berbeda signifikan, dimana bagian utara selat kedalaman yang terlihat mencapai $20 \mathrm{~m}$, sedangkan bagian selatan relatif lebih dalam yakni mencapai $36 \mathrm{~m}$. Secara melintang kedalaman tersaji dalam Gambar 2b, dari gambar 2b terihat perairan selat matak bagian barat terlihat lebih terjal bila dibandingkan dengan pantai bagian timur. 
Kemiringan pantai bagian barat mencapai $5.8^{\circ}$, sedangkan bagian timur sebesar $4.5^{\circ}$
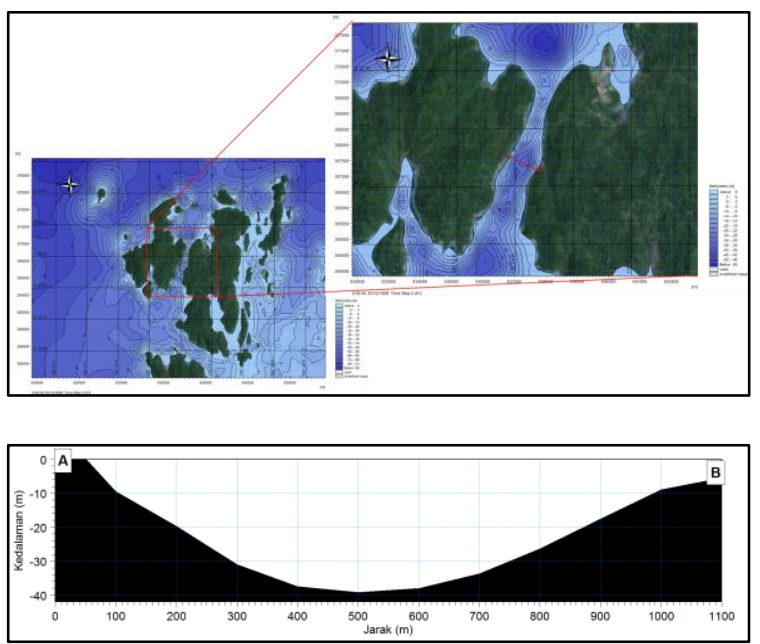

Gambar 2. Kedalaman perairan di wilayah kajian. (a) Kontur Kedalaman. (b) Profil melintang (barat-timur) kedalaman perairan

\subsection{Pasang Surut}

Pasang-surut (pasut) merupakan proses naik turunnya muka laut (sea level) secara teratur terutama disebabkan oleh gaya tarik bulan dan matahari. Oleh karena posisi bulan dan matahari terhadap bumi selalu berubah secara teratur, maka besarnya kisaran pasut juga berubah mengikuti perubahan tersebut. Pasut di lokasi kegiatan sangat dipengaruhi oleh rambatan pasut dari Laut Cina Selatan. Data komponen pasut dari Dinas Hidrooseanografi Tentara Nasional Indonesia Angkatan Laut (Dishidros TNI AL, 2012) stasiun Tarempa, Anambas tersaji dalam Tabel 2. Berdasarkan Tabel 2 komponen $\mathrm{K}_{1}$ dan $\mathrm{O}_{1}$ terlihat lebih dominan dibandingkan dengan komponen yang lainnya, kedua komponen tersebut merupakan komponen pasut tunggal. Komponen $\mathrm{K}_{1}$ merupakan pasut tunggal yang disebabkan oleh gaya tarik bulan, sedangkan komponen $\mathrm{O}_{1}$ merupakan komponen pasut tunggal yang di sebabkan oleh gaya tarik matahari. Hasil penentuan tipe pasut berdasarkan formulasi Formzahl diperoleh 3.58, yang artinya nilai tersebut dikelompokkan dalam tipe pasut tunggal. Hasil plot elevasi pasut disajikan dalam Gambar 3, gambar tersebut juga menunjukkan tipe pasang surut cenderung tunggal, yang artinya dalam sehari terjadi 1 kali pasang dan 1 kali surut.

\subsection{Gelombang}

Data gelombang yang digunakan dalam studi ini adalah tinggi gelombang signifikan rata-rata bulanan yang didperoleh dari data keluaran model
WAVEWATCH III NOAA. Data gelombang tersebut dapat diperoleh secara gratis melalui situs internet. Data gelombang selanjutnya divisualisasi dalam bentuk gambar kontur tinggi gelombang dengan menggunakan perangkat lunak ODV

Gelombang permukaan laut yang dominan umumnya dibangkitkan oleh adanya angin.Pembentukan gelombang permukaan yang merambat ke dalam perairan wilayah studi terjadi di laut lepas Cina Selatan. Gambar 4 adalah tinggi gelombang signifikan rata-rata bulanan yang diperoleh dari data keluaran model WAVEWATCH III. Dua panel gambar tersebut masing-masing adalah kontur tinggi gelombang bulan januari (gambar kiri) dan kontur tinggi gelombang bulan agustus (gambar kanan). Kedua gambar tersebut adalah representasi gelombang musiman, dimana gelombang bulan Januari mewakili musim barat, sedangkan bulan Agustus mewakili gelombang musim timur. Kedua panel tersebut menunjukkan pola perambatan gelombang yang sama, yakni gelombang merambat dari Laut Cina Selatan. Perbedaan yang terlihat hanya pada ketinggian gelombang signifikan, dimana pada saat musim barat (bulan Januari) gelombang yang merambat ke lokasi kajian terlihat lebih tinggi yang mencapai $1.8 \mathrm{~m}$, sedangkan pada saat musim timur (bulan Agustus) rata-rata tinggi gelombang terlihat lebih rendah, yakni hanya sekitar $0.6 \mathrm{~m}$.

\subsection{Arus Pengukuran}

Pengukuran arus selama 3 hari secara terusmenerus telah di lakukan untuk melihat kondisi arus sesaat di lokasi studi. Hasil pengukuran arus di visualisasi dalam bentuk grafik yang tersaji dalam Gambar 5 dan Gambar 6.

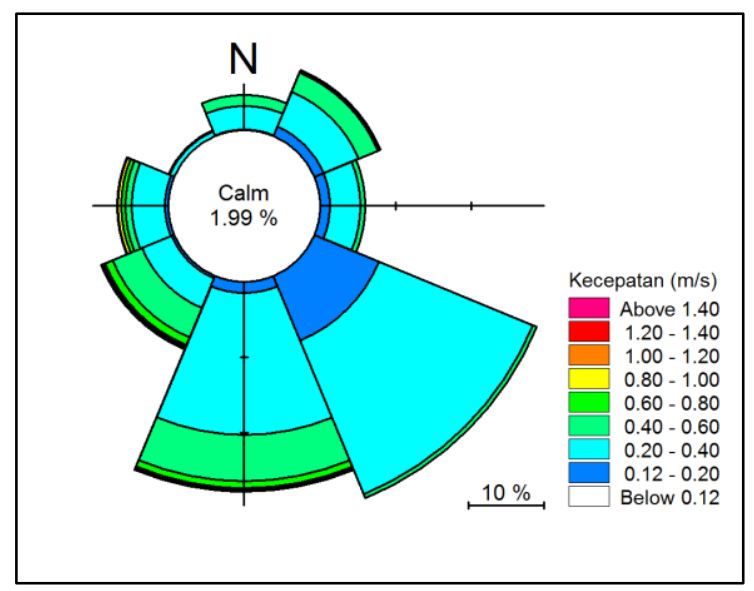

Gambar 6. Mawar Arus Yang Menunjukkan Arah Kejadian Arus.

Berdasarkan kedua gambar tersebut terlihat kecepatan arus berkisar 0,07 - $1.4 \mathrm{~m} / \mathrm{s}$, dengan ratarata $0.31 \mathrm{~m} / \mathrm{s}$. Kecepatan arus di lokasi studi 
tergolong rendah, hal ini di karenakan lokasi studi merupakan perairan semi tertutup dimana arus di dominasi oleh arus pasang surut. Arah arus dominan bergerak ke selatan-tenggara pada saat menjelang pasang hingga pasang, sebaliknya ketika menjelang surut hingga surut arus dominan menuju ke utara timur laut. Gambar yang menunjukkan pola pergerakan arus di sajikan dalam Gambar 7

\subsection{Verifikasi Model}

\subsubsection{Pola Arus Pemodelan}

Pemodelan pola arus dilakukan untuk mengetahui karateristik pola arus secara spasial dan temporal dilokasi studi.Simulasi pemodelan dilakukan pada bulan januari (mewakili musim barat) dan bulan agustus (mewakili musim timur). Hasil pemodelan di cuplik pada empat kondisi pasang surut yang dianggap ekstrim mempengaruhi pola gerak air, keempat kondisi tersebut adalah menjelang pasang, saat pasang, menjelang surut, dan saat surut. Hasil model disajikan dalam bentuk gambar vektor yang dioverlay dengan data kedalaman perairan

\subsubsection{Arus Musim Barat}

Hasil model pola arus musim barat berturutturut disajikan dalam Gambar 7 hingga Gambar 10.Gambar 7 merupakan hasil simulasi model pola arus menjelang pasang saat musim barat. Dari Gambar 7 terlihat pola arus menjelang pasang secara umum bergerak menuju ke arah selatan, hal ini menunjukkan peran pasang surut cukup kuat mempengaruhi pergerakan air di lokasi studi, dimana pada saat menjelang pasang naiknya muka laut lepas dari Laut Cina Selatan akan menimbulkan dorongan massa air bergerak ke arah selatan. Kecepatan arus di dalam selat saat menjelang pasang pada musim barat mencapai $1 \mathrm{~m} / \mathrm{s}$

Gambar 8 merupakan hasil simulasi model pola arus saat pasang pada musim barat.Peta berasal dari www.google earth.com Dari gambar tersebut terlihat arus masih bergerak menuju ke selatan. Pada umumnya di area pantai pada saat pasang arus cenderung stagnan (arus berjecepatan kecil), akan tetapi pada kasus ini arus masih bergerak menuju ke selatan dengan kecepatan sedikit lebih rendah bila dibandingkan dengan menjelang pasang. Bergeraknya arus menuju selatan ini sangat erat kaitanya dengan angin yang bergerak menuju ke selatan. Kecepatan arus maksimum di dalam selat saat pasang mencapai $0.32 \mathrm{~m} / \mathrm{s}$, sedangkan kecepatan rata-ratanya di area model adalah 0.12 $\mathrm{m} / \mathrm{s}$.

Gambar 9 dan Gambar 10 masing-masing merupakan hasil simulasi model arus menjelang surut dan saat surut pada musim barat.Dari Gambar 9 terlihat pola arus masih bergerak menuju ke selatan, hal ini semakin memperkuat dugaan bahwa selain pasang surut peran angin juga sangat dalam mengerakkan arus, dalam hal ini arus bergerak menuju ke selatan.Kecepatan arus saat menjelang surut terlihat tidak begitu berbeda dibandingkan dengan kecepatan arus menjelang pasang. Kecepatan arus menjelang surut di dalam selat mencapai 0.85 $\mathrm{m} / \mathrm{s}$

Hasil simulasi model arus saat surut pada musim barat disajikan dalam Gambar 10. Pola arus saat surut (Gambar 10) menunjukkan adanya perbedaan dengan 3 kondisi sebelaumnya, yakni arus di dalam selat bergerak keluar ke utara menuju Laut Cina Selatan.Dalam kondisi surut terlihat peran pasut lebih dominan bila dibandingkan angin, hal ini terbukti walaupun angin menuju ke selatan, arus di dalam selat bergerak menuju ke utara mengikuti aliran pasut yang menuju ke laut cina selatan. Dari Gambar 12 juga terlihat kecepatan arus cukup bervariasi dilokasi pemodelan, kecepatan arus saat surut di dalam mencapai $0.5 \mathrm{~m} / \mathrm{s}$, dengan rataratanya $0.15 \mathrm{~m} / \mathrm{s}$

\subsubsection{Arus Musim Timur}

Hasil simulasi model pola arus bulan Agustus (musim timur) disajikan seperti halnya pada musim barat, yakni di cuplik pada waktu menjelang pasang, saat pasang, menjelang surut, dan saat surut.Keempat kondisi arus tersebut masing-masing disajikan dalam Gambar 11 hingga Gambar 14. Secara umum dari keempat gambar tersebur terlihat pola arus pada musim timur menunjukkan ada sedikit perbedaan bila dibandingkan dengan kondisi musim barat, perbedaan ini terlihat pada saat menjelang surut. Pada saat musim barat kondisi menjelang surut, arus masih bergerak menuju ke arah selatan, sedangkan pada saat musim timur kondisi menjelang surut arus bergerak menuju ke utara. Perbedaan ini di sinyalir karena pada kondisi menjelang surut peran angin lebih dominan bila dibandingkan peran pasut dalam pembangkitan arus. Kondisi angin pada musim barat dominan bergerak ke arah selatan, sebaliknya pada musim timur arus dominan bergerak menuju ke arah utara.

Gambar 11 adalah pola arus menjelang pasang saat musim timur, dimana pola arus dominan bergerak menuju ke selatan dengan kecepatan lebih rendah bila dibandingkan dengan musim barat, yakni di dalam selata hanya mencapai $0.75 \mathrm{~m} / \mathrm{s}$. Pada saat pasang (Gambar 12) pola arus hasil simulasi masih mengarah ke selatan dengan kecepatan lebih rendah dari kecepatan arus saat menjelang pasang. Kecepatan arus hasil simulasi model pola arus maksimum saat pasang pada musim timur di dalam 
selat $0.25 \mathrm{~m} / \mathrm{s}$ dengan rata-rata kecepatan arus dari keseluruhan area model sebesar $0.11 \mathrm{~m} / \mathrm{s}$.

Gambar 13 di bawah merupakan hasil simulasi model pola arus menjelang surut pada musim timur, dari gambar tersebut terlihat pola arus mulai bergerak ke arah utara atau bergerak menjauhi pantai mengarah ke Laut Cina Selatan. Kecepatan arus kondisi menjelang surut pada musim timur mencapai $0.35 \mathrm{~m} / \mathrm{s}$.Hasil simulasi model pola arus saat surut pada musim timur diperlihatkan dalam Gambar 14.Pola arus hasil simulasi model saat surut pada musim timur terlihat tidak begitu berbeda dengan pola arus saat surut pada musim barat, yakni arah arus menuju ke utara. Kecepatan arus hasil model pada saat surut pada musim timur mencapai $0.5 \mathrm{~m} / \mathrm{s}$ dengan rata-rata dari keseluruhan domain model sebesar $0.25 \mathrm{~m} / \mathrm{s}$.

\section{KESIMPULAN}

Dari hasil model hidrodinamika perairan dan kondisi oseanografi di Selat Matak Kabupaten Kepulauan Anambas dapat diambil kesimpulan sebagai berikut:

- Pemodelan pola arus terbagi menjadi 2 musim, yaitu musim barat dan musim timur Simulasi pemodelan dilakukan pada bulan januari (mewakili musim barat) dan bulan agustus (mewakili musim timur).

- Pola arus menjelang pasang saat musim barat secara umum bergerak menuju ke arah selatan, hal ini menunjukkan peran pasang surut cukup kuat mempengaruhi pergerakan air di lokasi studi, dimana pada saat menjelang pasang naiknya muka laut lepas dari Laut Cina Selatan akan menimbulkan dorongan massa air bergerak ke arah selatan. Kecepatan arus di dalam selat saat menjelang pasang pada musim barat mencapai $1 \mathrm{~m} / \mathrm{s}$.

- Pola arus saat pasang pada musim barat terlihat arus masih bergerak menuju ke selatan. Bergeraknya arus menuju selatan ini sangat erat kaitanya dengan angin yang bergerak menuju ke selatan. Kecepatan arus maksimum di dalam selat saat pasang mencapai $0.32 \mathrm{~m} / \mathrm{s}$, sedangkan kecepatan rata-ratanya di area model adalah $0.12 \mathrm{~m} / \mathrm{s}$.

- Pola arus menjelang surut masih bergerak menuju ke selatan, hal ini semakin memperkuat dugaan bahwa selain pasang surut peran angin juga sangat signifikan dalam mengerakkan arus, dalam hal ini arus bergerak menuju ke selatan. Kecepatan arus saat menjelang surut mencapai $0.85 \mathrm{~m} / \mathrm{s}$

- Pola arus saat surut menunjukkan adanya perbedaan dengan 3 kondisi sebelumnya, yakni arus di dalam selat bergerak keluar ke utara menuju Laut Cina Selatan. Dalam kondisi surut terlihat peran pasut lebih dominan bila dibandingkan angin, hal ini terbukti walaupun angin menuju ke selatan, arus di dalam selat bergerak menuju ke utara mengikuti aliran pasut yang menuju ke laut cina selatan. Kecepatan arus cukup bervariasi dilokasi pemodelan, kecepatan arus saat surut di dalam mencapai $0.5 \mathrm{~m} / \mathrm{s}$, dengan rata-ratanya 0.15 $\mathrm{m} / \mathrm{s}$.

\section{DAFTAR PUSTAKA}

- Chapra, 1997.Surface water quality modelling.McGraw-Hill. Singapore.

- Dishidros TNI AL. 2012. Peta Kedalaman PulauPulau Anambas. Lembar Peta 182. Jakarta

- Hydrodynamics Module of MIKE 21 Flow Model, 2007. Scientific Documentation, DHI Water Environmental. Denmark. $58 \mathrm{p}$

- MIKE. 2005. Environmental Hydraulics Advection, Dispersion Module, scientific Documentation, DHI Software.

- http://www.earth.google.com

- http://www.ecmwf.int. 
Tabel 2. Konstanta Harmonik Pasang Surut Stasiun Tarempa, Perairan Anambas Kepulauan Riau.

\begin{tabular}{|l|c|c|c|c|c|c|c|c|c|c|}
\hline \multicolumn{10}{|c|}{ Komponen Pasut Tarempa, Anambas } \\
\hline & $\mathbf{S}_{2}$ & $\mathbf{M}_{2}$ & $\mathbf{K}_{1}$ & $\mathbf{O}_{1}$ & $\mathbf{P}_{1}$ & $\mathbf{N}_{2}$ & $\mathbf{K}_{2}$ & $\mathbf{M}_{4}$ & $\mathbf{M S}_{4}$ & $\mathbf{Z}_{\mathbf{0}}$ \\
\hline Amplitudo $(\mathrm{cm})$ & 3 & 16 & 38 & 30 & 13 & 4 & 1 & 1 & 0 & 110 \\
\hline Fase (Deg) & 79 & 144 & 11 & 50 & 11 & 182 & 79 & 195 & 121 & \\
\hline
\end{tabular}

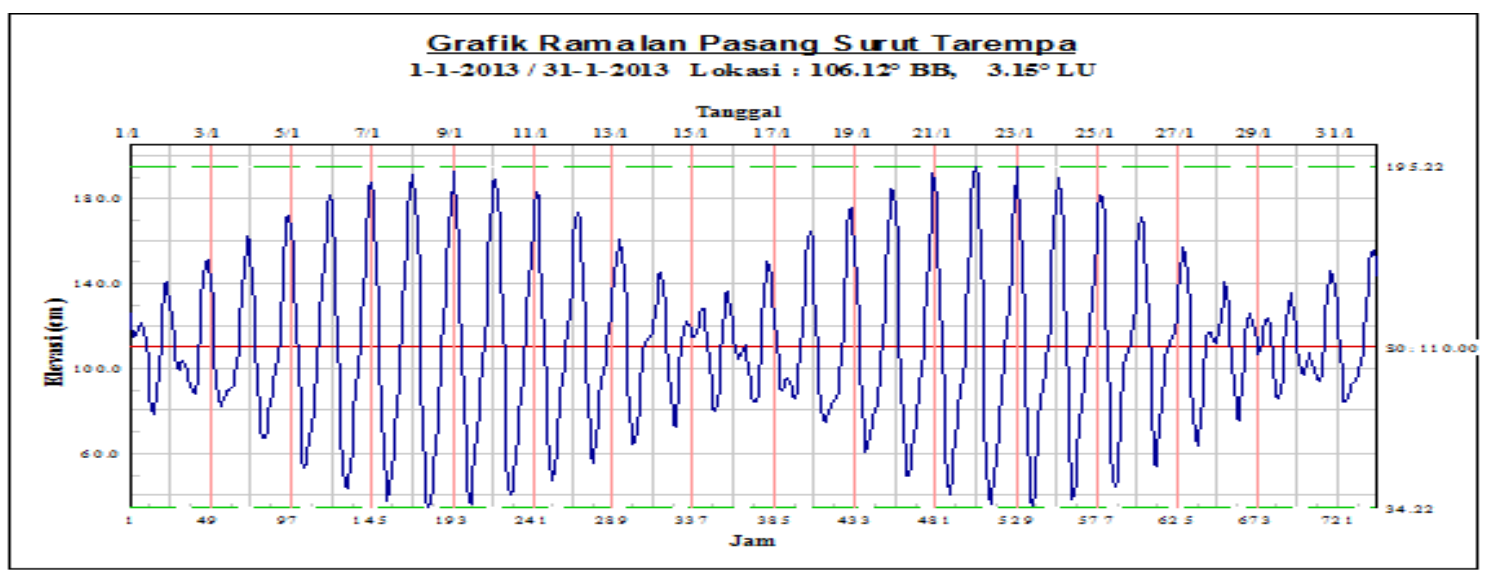

Gambar 3. Grafik Elevasi Pasang Surut Selama 30 Hari.

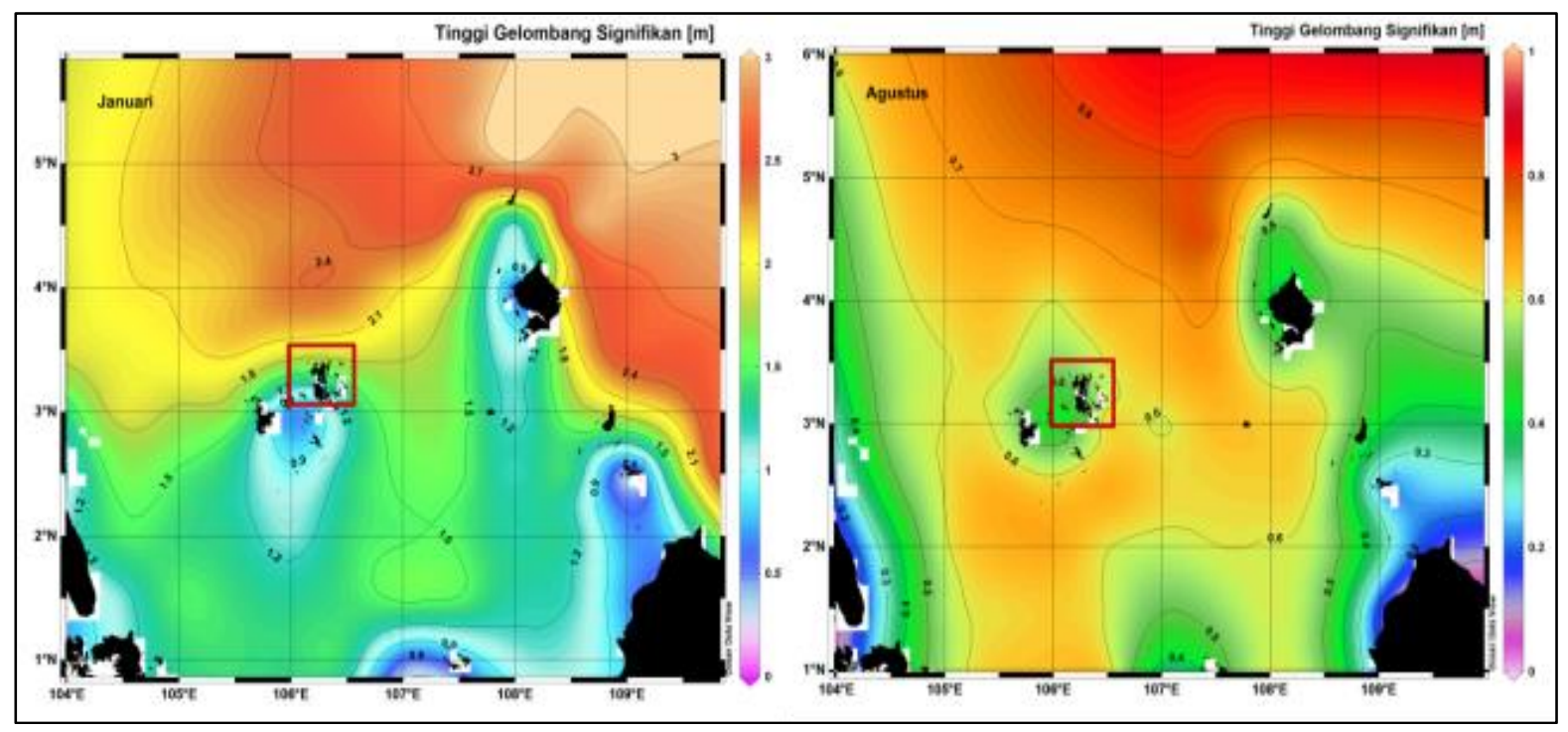

Gambar 4. Tinggi Gelombang Signifikan Rata-Rata Bulanan Yang Merambat Memasuki Perairan Wilayah Studi.

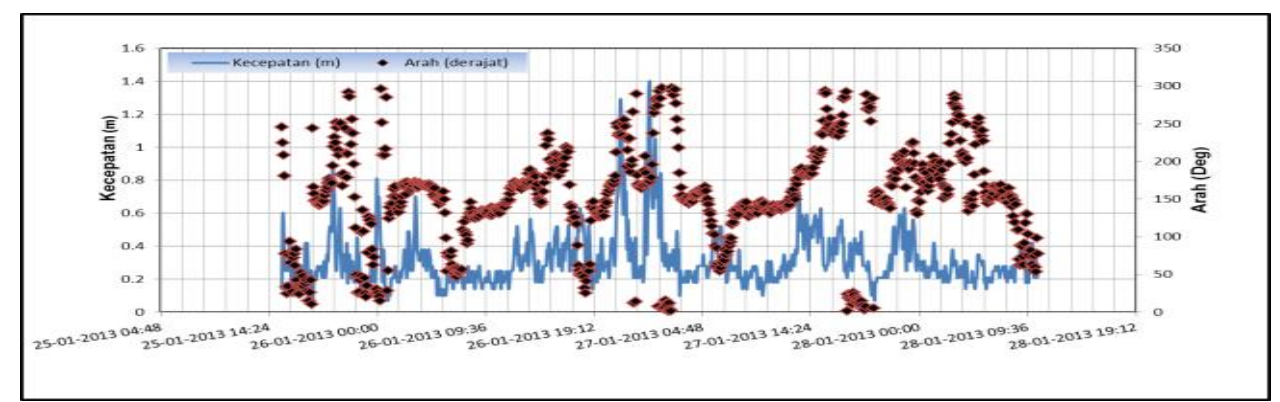

Gambar 5. Arah dan kecepatan arus dalam bentuk grafik series selama 3 hari 


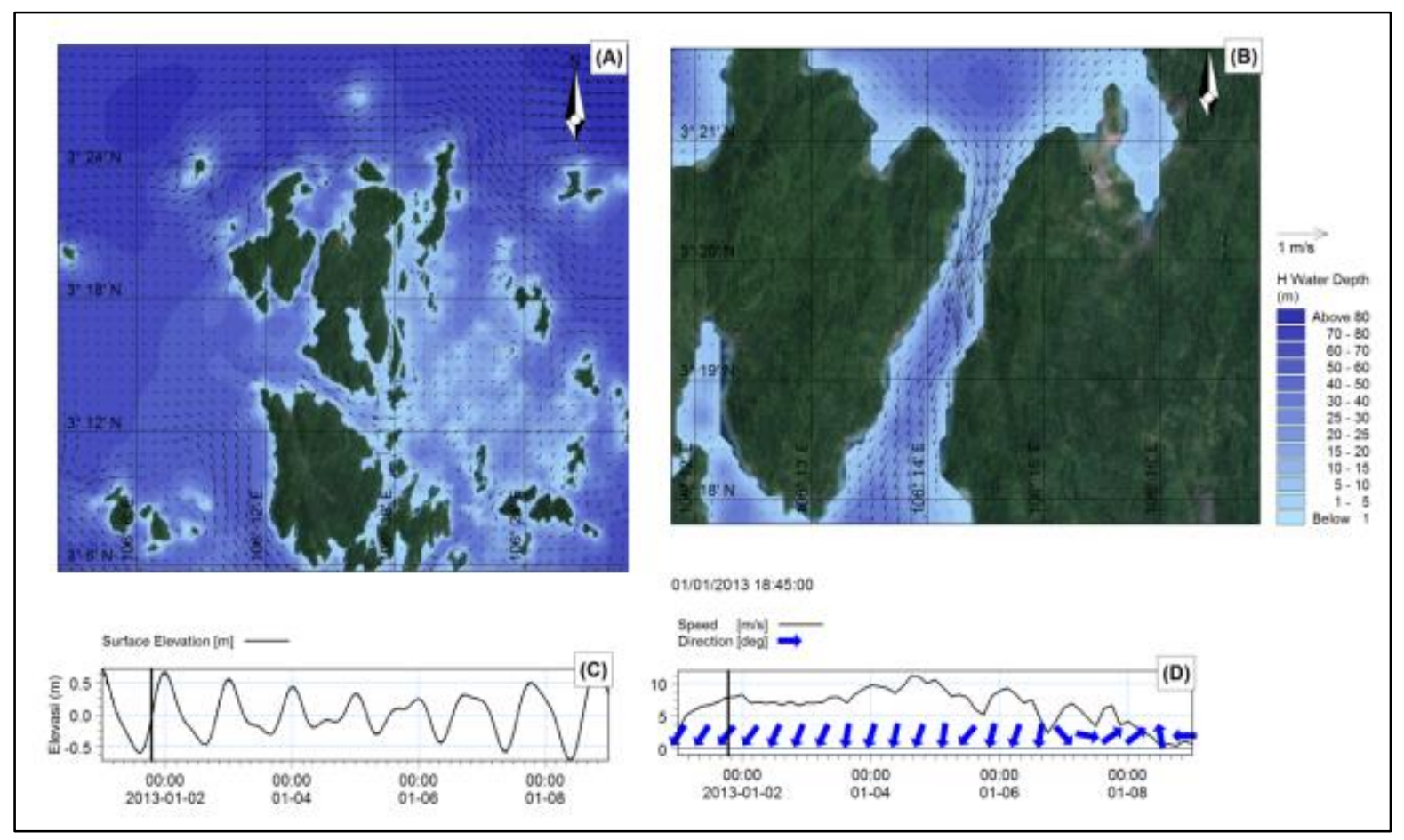

Gambar 6. Pola arus menjelang pasang saat musim barat. (A) Vektor arus yang dioverlay dengan kedalaman. (B) pola arus area fokus kajian. (C) Pasut area kajian (D) angin input model.

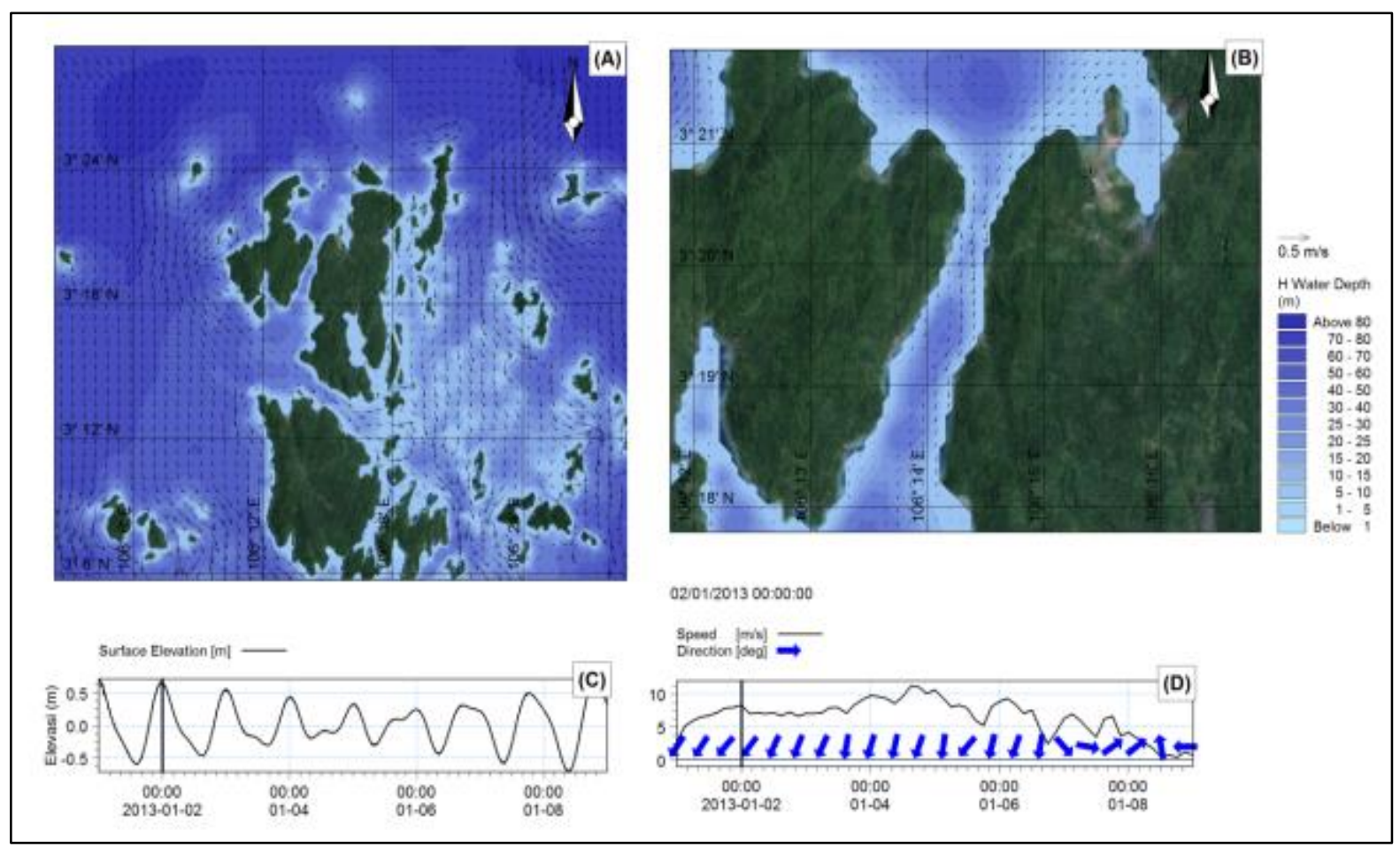

Gambar 7. Pola Arus Saat Pasang Pada Musim Barat. (A) Vektor Arus Yang Dioverlay Dengan Kedalaman.(B) Pola Arus Area Fokus Kajian.(C) Pasut Area Kajian (D) Angin Input Model. 


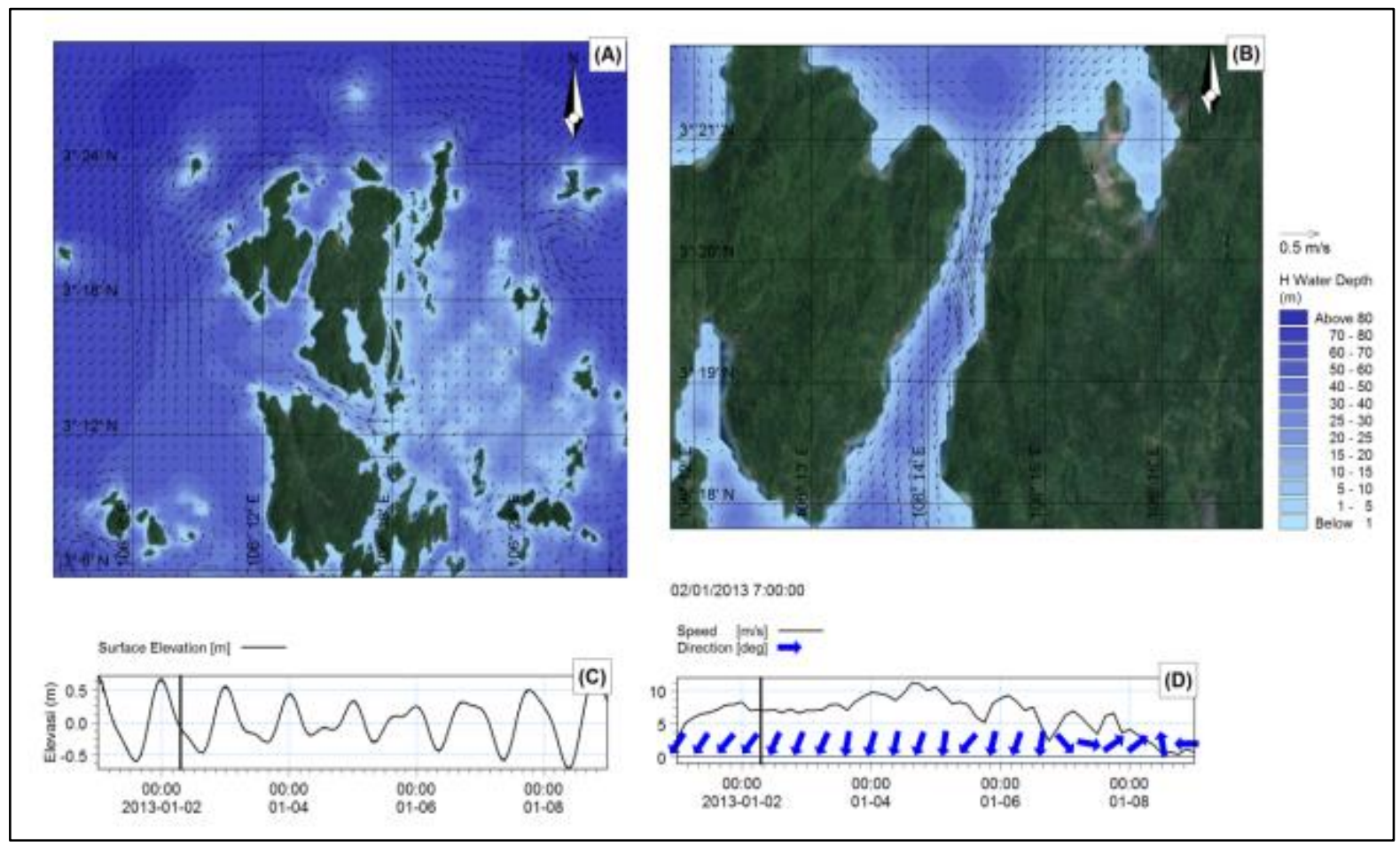

Gambar 1.Pola Arus Menjelang Surut Saat Musim Barat. (A) Vektor Arus Yang Dioverlay Dengan Kedalaman.(B) Pola Arus Area Fokus Kajian.(C) Pasut Area Kajian (D) Angin Input Model.

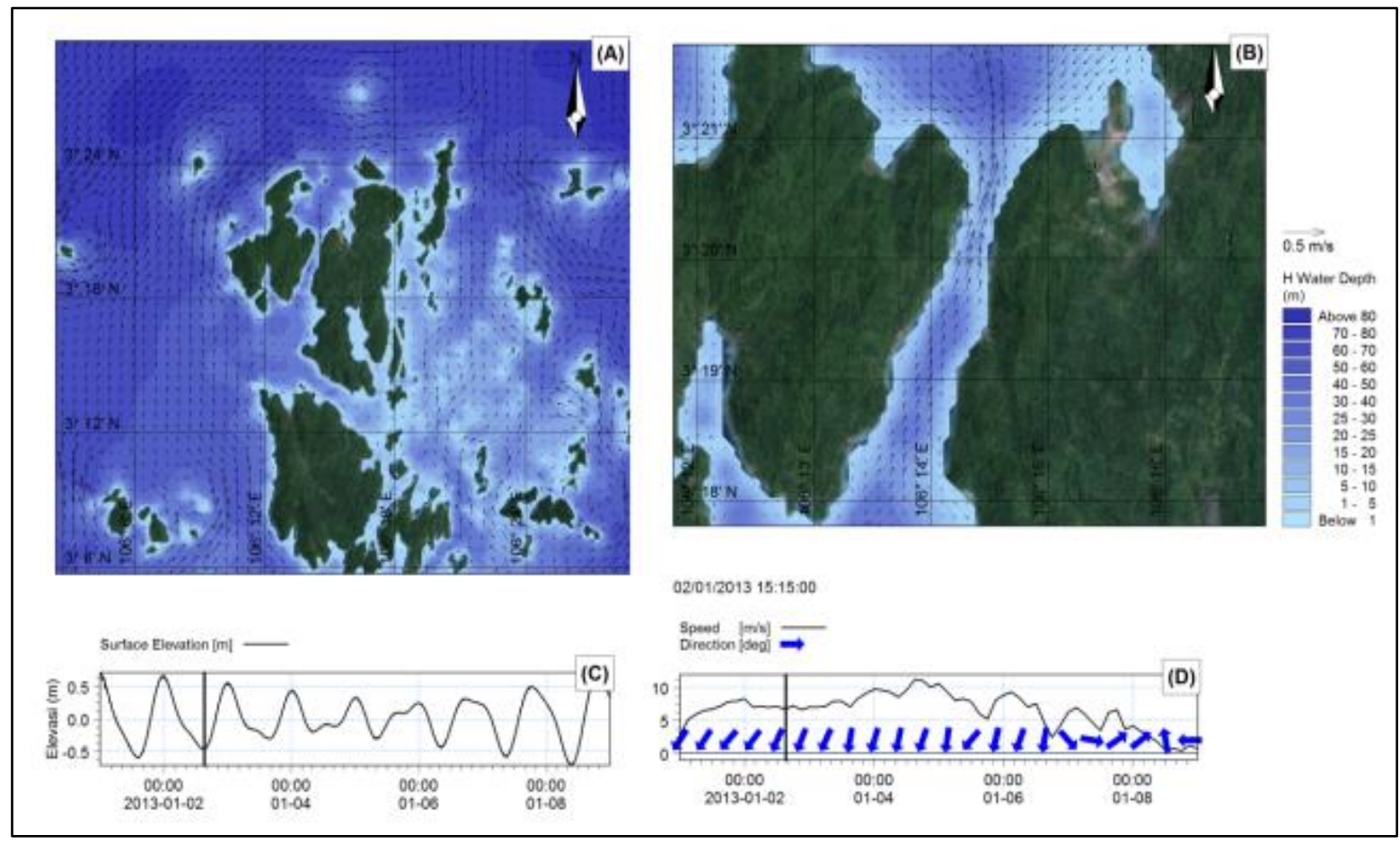

Gambar 2.Pola Arus Saat Surut Pada Musim Barat. (A) Vektor Arus Yang Dioverlay Dengan Kedalaman.(B) Pola Arus Area Fokus Kajian.(C) Pasut Area Kajian (D) Angin Input Model. 


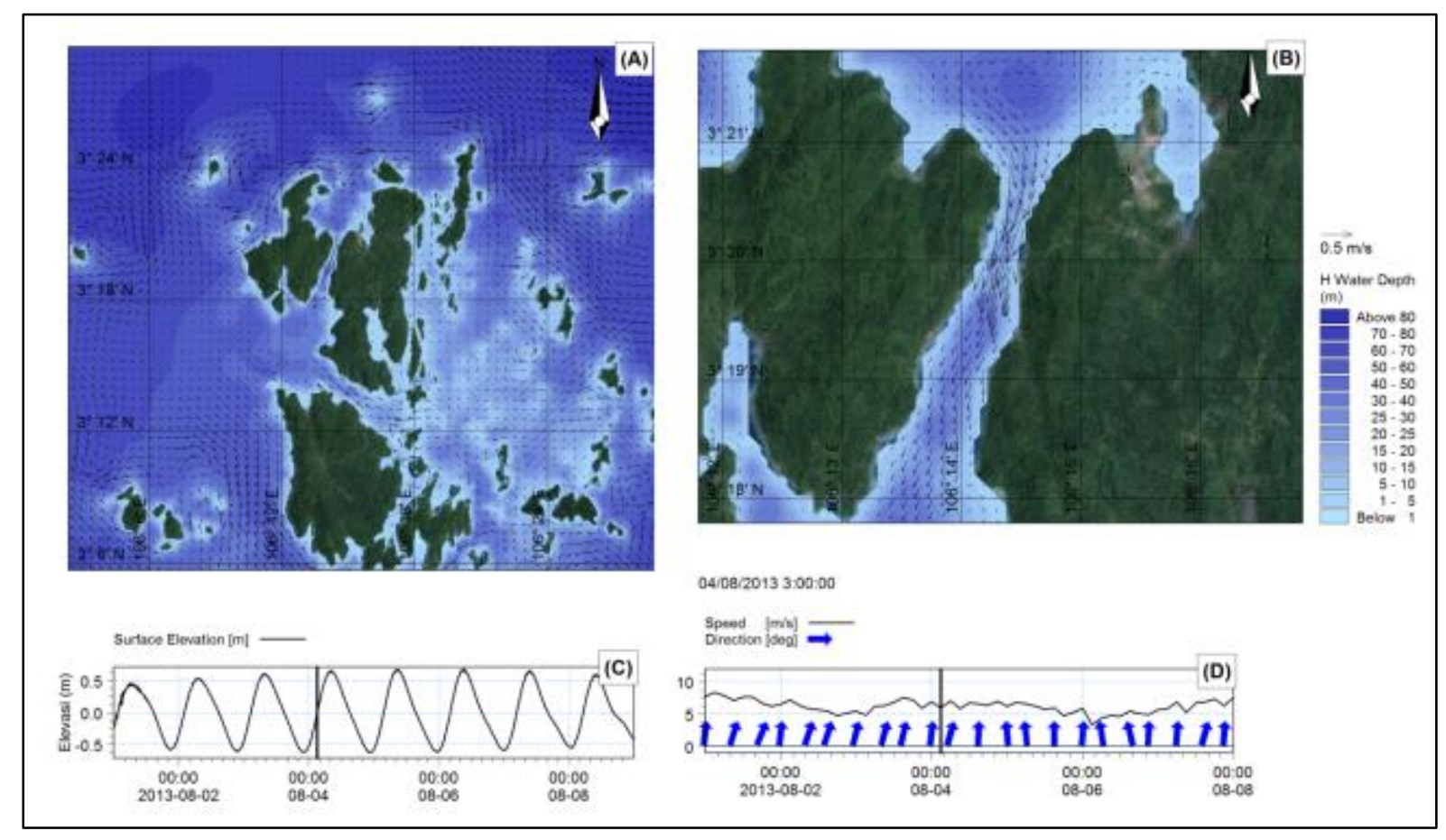

Gambar 3.Pola Arus Menjelang Pasang Saat Musim Timur. (A) Vektor Arus Yang Dioverlay Dengan Kedalaman.(B) Pola Arus Area Fokus Kajian.(C) Pasut Area Kajian (D) Angin Input Model.

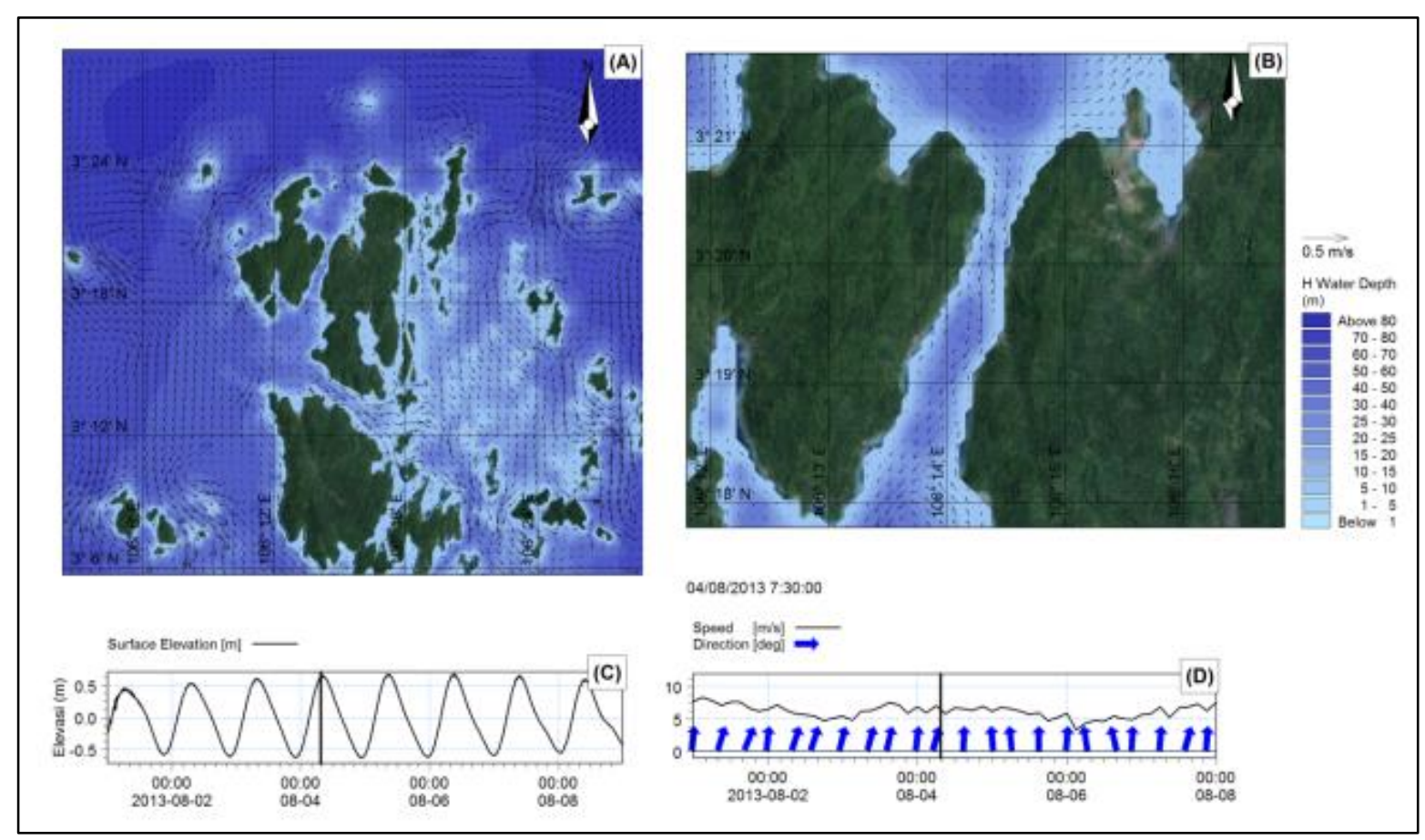

Gambar 4.Pola Arus Saat Pasang Pada Musim Timur. (A) Vektor Arus Yang Dioverlay Dengan Kedalaman.(B) Pola Arus Area Fokus Kajian.(C) Pasut Area Kajian (D) Angin Input Model. 


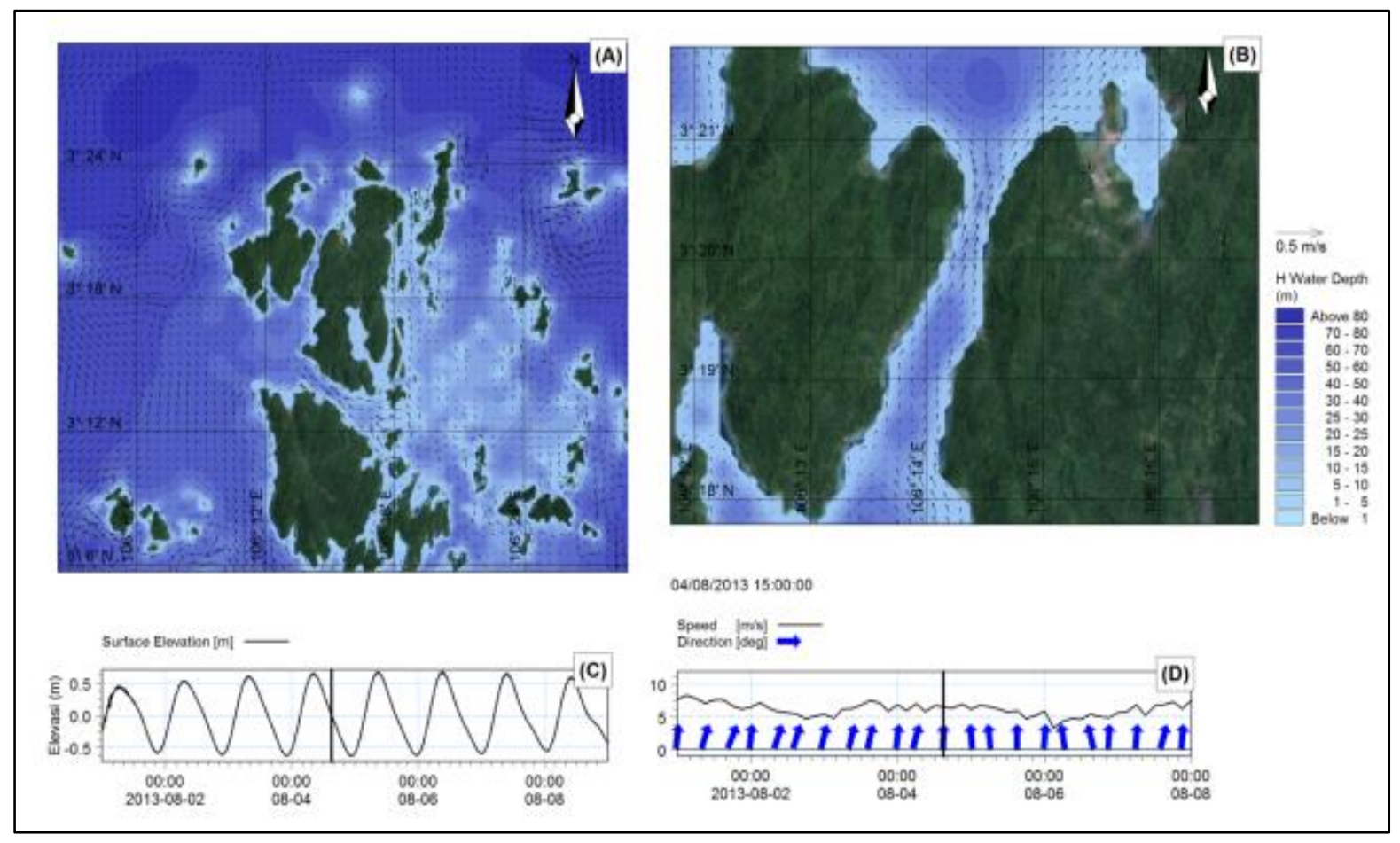

Gambar 5.Pola Arus Menjelang Surut Saat Musim Timur (A) Vektor Arus Yang Dioverlay Dengan Kedalaman.(B) Pola Arus Area Fokus Kajian.(C) Pasut Area Kajian (D) Angin Input Model.

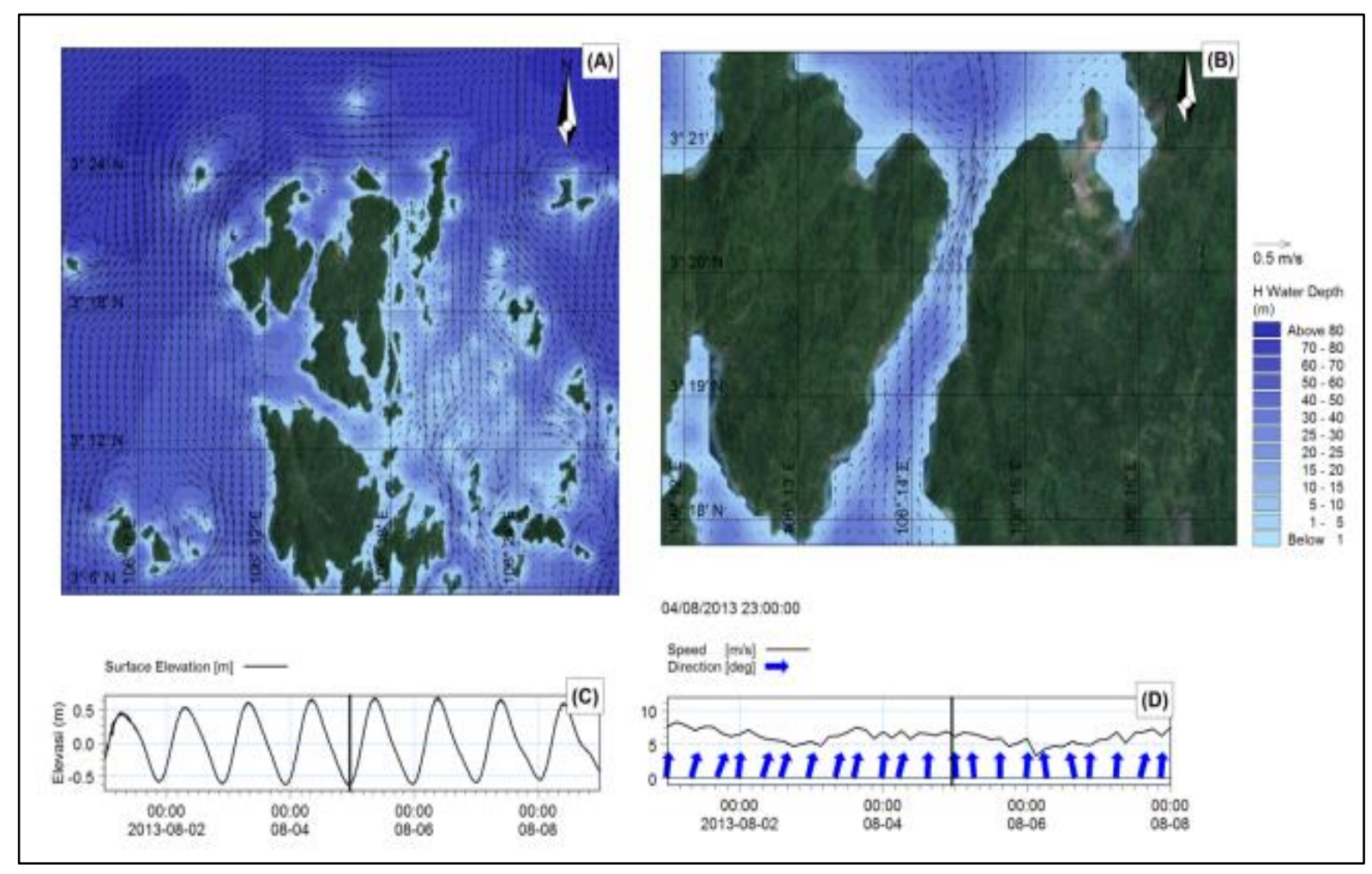

Gambar 6.Pola Arus Saat Surut Pada Musim Timur. (A) Vektor Arus Yang Dioverlay Dengan Kedalaman.(B) Pola Arus Area Fokus Kajian.(C) Pasut Area Kajian (D) Angin Input Model. 